\title{
MANNEQUINS IN A SHOP WINDOW AS AN OBJECT OF SCIENTIFIC CONSIDERATION
}

\section{Oksana Lahoda ${ }^{1}$ Liu Peiwei ${ }^{2}$}

\section{DOI: https://doi.org/10.30525/978-9934-588-52-5-3}

In the twentieth century, the arrangement of shop windows became a separate sphere of creative activity which is now known as «window dressing». It is considered a component of visual merchandising (promotion of goods), which in turn is a set of actions in an outlet to increase demand for goods. Visual merchandising is a special art of goods presentation, and window dressing is a unique marketing tool that implements the requirements for advertising of different goods and different manufacturers. I. Bondarenko and N. Sohomonian emphasize that the external shop window is a unique freeof-charge advertising space, which broadcasts the «stories» about the goods created by specialists by means of shape, colour, and light [1, p. 16]. The key functions of shop windows are to inform and to advertise the goods. At the same time, the shop window is considered an ideal tool of influence, a powerful tool for manipulating various marketing strategies.

Window dressing is a practical area of designers' activity as a type of exhibition design. However, modern shop windows often resemble installations and are perceived as art objects - conceptual works of modern art, associated with the name of a particular store or a brand [2]. Among the factors that contributed to the development of «the art of visual sales», scientists identify the following:

- Intensive development of retail trade, growth of industrial production of various goods;

- Organization of trade in the conditions of operation of department stores;

- Experiments of artists and designers that influence the change of forms of presentation of goods and their design [3].

These conditions became relevant at the turn of the nineteenth and the twentieth centuries but became especially acute in the middle of the twentieth century in the conditions of intensive development of mass consumption. The display of the goods has formed the need for a professional design of shop windows. Thus, the history of the development of shop windows has become a process of developing special techniques and methods of informing

\footnotetext{
${ }^{1}$ Kharkov State Academy of Design and Fine Arts, Ukraine

${ }^{2}$ Kharkov State Academy of Design and Fine Arts, Ukraine
} 
consumers in a visual way - visually in the creation of autonomous objects of exhibition design.

The shop windows demonstrate not only the availability of goods and their price. They point to the benefits, properties, and quality of the goods by informing, advertising, and selling them. To create such information and advertising objects, various artistic means, compositional and constructive methods of shaping and special equipment for exhibitions are used. This gives the shop windows their sense, artistic and aesthetic meaning, and axiological value. It is important «what» is presented in the window, «how» and «by what means» it is presented [4]. This means that shop windows should be seen as a socio-cultural object, an exhibition design, and an artistic presentation with their respective functions.

Shop windows and their contents are also considered in the context of the problem caused by their functioning in the city environment, among the variety of advertising and in terms of impact on the passers-by. In science, this problem is associated with the problem of «visual perception», with ethics and aesthetic impact on a person. This is also a problem of visual ecology. The following questions remain relevant: what is really a shop window, what functions does it perform, how does the interaction of the manufacturer of the goods, their seller, and the consumer take place? A special question is a role that the mannequin plays as special equipment.

The study of functions, analysis of images, style, etc. in the design of mannequins allows solving a number of modern art problems. The mannequins are used not only to show clothes and various goods. The mannequins imitate a person and their actions. The mannequins have their own «story», in which they have become a special formative element of the shop window display. This is evidenced by the existing classifications of mannequins [6]. They are created from a variety of materials, have different shapes, sizes, and colours. Each brand strives to have special creative mannequins for their goods. There are very interesting examples that impress the imagination. Besides, researchers pay great attention to mannequins for various experiments, for example, research on the quality of textiles, the particulars of goods fitting on the human body, the wearability of clothing in general. This indicates not only the artistic and aesthetic aspects of the design of mannequins but also a wide range of their functions as objects of design activities.

The consideration of mannequins in a shop window by modern science is undoubtedly relevant, because in a society with strong competition in the consumer goods market, the dressing of the shop windows has become especially important. The scientists' interest in shop window design was formed before the 1990s, in particular in the following areas: in the context of 
their uniqueness; as a component in the design of streets; on consideration of design principles; problems of their design in terms of marketing and economic feasibility. Meanwhile, the mannequins in the shop window, which are often given a more important role than the things on display, still remain unexplored.

\section{References:}

1. Bondarenko, I., \& Sohomonian, N. (2015). Kompozycijni pryjomy u vyrishenni dyzajnu vitryn suchasnykh maghazyniv [Compositional techniques in solving the design of modern storefronts]. HDADM Bulletin; Theory of arts, vol. 4, pp. 15-18.

2. Danilkina, O. (2010). Tri vitriny magazinov, kotorye oformili sovremennye khudozhniki i dizaynery [Three storefronts designed by contemporary artists and designers]. Retrieved from: http://www.lookatme.ru/flow/posts/design-radar/111845zdes-byl-hudozhnik-novye-vitriny-magazinov-v-parizhe-milane-i-moskve (19 February 2020).

3. Litvinov, V. V. (2006). Dizayn: Magazin, vitrina... [Design: Shop, showcase...] Moscow: Izdatel'stvo V. V. Litvinov. (in Russian)

4. Shealy, H. (2016). An Investigation Of Mannequins' Effect On Consumer Attitude And Intention. (Master's thesis). Retrieved from: https://scholarcommons.sc.edu/etd/3940 (accessed 19 February 2020).

5. Nayak R. (Ed.), Padhye R. (2017). Manikins for Textile Evaluation (The Textile Institute Book Series). Woodhead Publishing, 416 p. 